\title{
The Gay and Lesbian Counseling Process: An Alternative Religious Approach
}

Siti Hajar Jamal \& Nasrudin Subhi

To Link this Article: http://dx.doi.org/10.6007/IJARBSS/v11-i6/10228

DOI:10.6007/IJARBSS/v11-i6/10228

Received: 12 April 2021, Revised: 19 May 2021, Accepted: 30 May 2021

Published Online: 13 June 2021

In-Text Citation: (Jamal \& Subhi, 2021)

To Cite this Article: Jamal, S. H., \& Subhi, N. (2021). The Gay and Lesbian Counseling Process: An Alternative Religious Approach. International Journal of Academic Research in Business and Social Sciences, 11(6), 982-992.

\section{Copyright: @ 2021 The Author(s)}

Published by Human Resource Management Academic Research Society (www.hrmars.com)

This article is published under the Creative Commons Attribution (CC BY 4.0) license. Anyone may reproduce, distribute, translate and create derivative works of this article (for both commercial and non-commercial purposes), subject to full attribution to the original publication and authors. The full terms of this license may be seen at: http://creativecommons.org/licences/by/4.0/legalcode

Vol. 11, No. 6, 2021, Pg. 982- 992

Full Terms \& Conditions of access and use can be found at http://hrmars.com/index.php/pages/detail/publication-ethics 


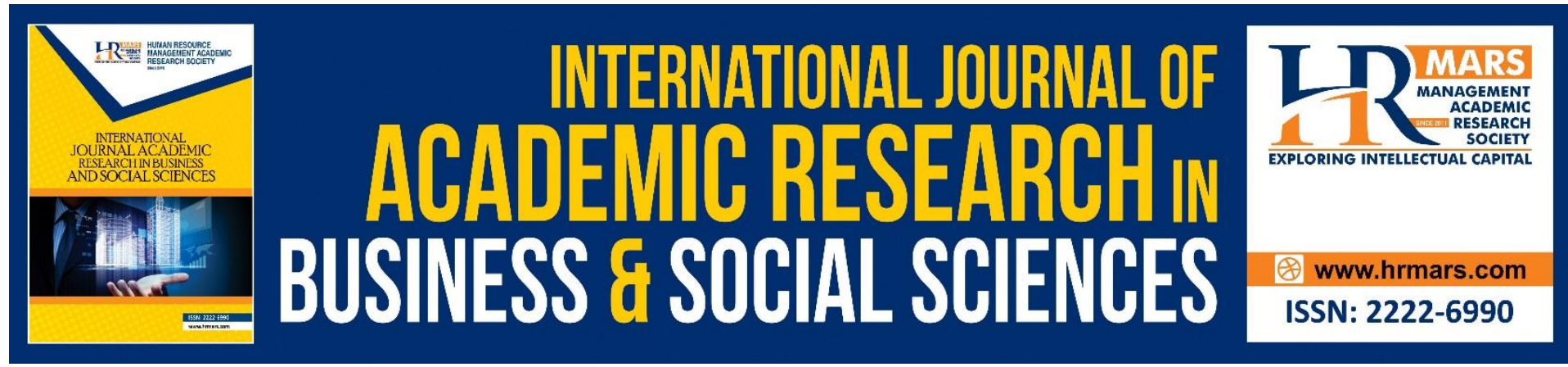

\title{
The Gay and Lesbian Counseling Process: An Alternative Religious Approach
}

\author{
Siti Hajar Jamal \& Nasrudin Subhi
}

Center for Research in Psychology and Human Well-Being, Faculty of Social Science and Humanities, The National University of Malaysia, 43600 Bangi, Selangor, Malaysia

Email: nas2572@ukm.edu.my

\begin{abstract}
Discussions on religious approaches in counseling procedures are still considered new, especially if they involve gay and lesbian clients. These people need help emotionally and spiritually to promote change and better emotional well-being in their lives. In order to sow the seeds of change, religious alternatives is important to be introduced in the counseling process especially in a society that still adheres strongly to religious matters. This study aims to explore the extent to which religious approaches can assist counselors in handling gay and lesbian cases. To obtain information, researchers use in-depth interviews through purposive sampling techniques. The study involved eight participants consisting of registered counselors who have had experienced conducting counseling sessions with gay and lesbian clients. Data were analyzed by examining the transcription of interview recordings and identifying emerging themes based on the objectives of the study using N-Vivo software 11 . The results of the study found that there are four main themes namely (i) religious practice (ii) client willingness and (iii) Ad-Din psychological approach and (iv) Islamic Creative Art Therapy (ICAT). In addition, the results of this study also explain that the religious approach can assist clients in getting better outcomes to return to origin. Thus, this study adds value to the existing counseling skills as well as counselors are able to increase their willingness and knowledge related to religious counseling. Overall, this will enable counseling sessions can be conducted in a sound and competent manner.
\end{abstract}

Keywords: Religious Approach, Counseling Process, Counselor, Gay Dan Lesbian

\section{Introduction}

Lately, gay and lesbian issues have been actively debated and widely covered by the media. This group is often criticized and condemned by society, but nonetheless get support and backing from social activists who rose to fight for human rights so that this group is not further discriminated against (Wahyuni et al., 2020). This is because the wave of western culture with secularist ideology can easily spread into society and in turn affect a person's mind and behavior (Hajar, 2020; i Hajar et al., 2020). However, from the viewpoint of a counselor, gays and lesbians need to be helped and they should not be marginalized. In fact, they are also entitle as client in seeking counseling services (Wahyuni et al., 2020). According to Amran \& Noriah (2014) homosexual behavior is a problem that involves the internal self which reflects 
in their way of life. Therefore, the alternative treatment that is seen as suitable to be applied in sexual problems is through religious approach. Norliah \& Mahadi (2006) who indicated that to address sexual misconduct and social problems is to return to religious teachings also support this opinion. In Malaysia, the counseling approach applied is based on counseling practices from the western world; therefore, at times it is seen as less fitting for use on Muslim clients (Roslee et al., 2008). Pedersen (1989) states that counselors in Asia need to be sensitive to the needs and wants of eastern societies that have different cultural values. Ivey et al (2005) stated that the counseling services provided should take into account various aspects including cultural, religious and spiritual so that the counseling services conducted are effective and can help clients. Thus, the approach or religious counseling is seen to be alternatively effective and suitable to be applied to clients' especially involving sexual and spiritual problems.

Thus, in addition to the use of conventional theories from the west, it was found that counselors used religious approach when conducting sessions with gay and lesbian clients. Religious issues in counseling cases can be a fundamental therapeutic element in conducting counseling sessions to clients (Sperry, 2007; Sperry \& Shafranske, 2005). There are developments to empirical evidence stating that religious and behavioral values can improve a client's psychological and physical well-being. Thus, religiosity is an important component of mental health and the practical integration of counseling in enhancing the therapeutic process in counseling (Corey, 2009). The use of religious values in this counseling session is to understand the client's worldview and the context of the client's life that can assist the client in understanding their life purpose, their desires as well as exploring the religion held by the client. Amran and Noriah (2014) have suggested that counselors can use religious alternative treatments as a primary treatment in helping clients with gay and lesbian problems in Malaysia. They also found that alternative spiritual or religious approaches were seen as relevant and suitable to be used to help those involved with gay and lesbian issues. They also argue that this religious alternative can be combined with Psychoanalytic Theory in facing challenges as well as formulating treatment action plans for gays and lesbians who want to return to origin.

At the same time, Noor et al. (2016) have looked at the appropriateness of da'wah and methods of approaching lesbians and gays. This study emphasizes five methods that can help lesbian and gay clients namely $d a^{\prime}$ wah $\mathrm{Bi} \mathrm{Al}-\mathrm{Hal}$, entertainment, social coaching, psychological approach and personality development. Therefore, caring for this community group is the core in the context of the implementation of the dakwah methodology towards the LGBT community. By nature, humans like to live together and in groups. Humans cannot be alone all the time. Humans need each other to survive, thus human beings are a social society because human beings are constantly interacting with each other. In search of innovation in providing assistance services including counseling, various new approaches were created. From the Islamic perspective, among the newly approaches introduced in an effort to diversify aspects of exploration in counseling is an approach known as Islamic Creative Art Therapy (ICAT). The Negeri Sembilan Islamic Religious Council Counseling Center first introduced I-CAT to the public during the organization of the Islamic Creative Art Therapy Seminar that was held at the national level in 2017. I-CAT incorporates the Islamic approach into creative art therapy used to assist clients including gays and lesbians clients in an effort to unravel their problems. As there has not been a holistic study in exploring the competence of counselors 
in dealing with gay and lesbian issues in Malaysia, this study has been implemented. In discussing the competence of counselors in dealing with gay and lesbian issues, the use of a religious approach is no exception and the exploration of this matter is the goal of this journal article.

\section{Research Methodology}

This study used a qualitative study design that involved semi-structured in-depth interviews. The selection of study participants was selected using a purposive sampling method targeted at counselors with experience in conducting counseling sessions with gay and lesbian clients. Patton (2002) explains that sampling aims to help researchers understand better. This is because the study participants involved are rich in information as well as in line with the purpose of the study conducted (Sabitha, 2005).

Eight study participants were selected to participate in this study voluntarily. The number of participants in this study was sufficient to obtain rich data for a qualitative study (Creswell, 2012; Hill et al., 1997; Yin, 2015). The data of this study were obtained using a semi-structured in-depth interview technique. The interview protocol was constructed based on the literature related to the study that had been conducted. For the procedure of analyzing the study data, the researcher has chosen the approach of three stages of data analysis by Miles \& Huberman (1994) namely filtering, presentation and concluding together with validating the data. Next, the analysis of the study used was by using verbatim and turning it into a transcript (Miles \& Huberman, 1994; Yin, 2015). Data was collected from various sources through interviews and document analysis, so to understand this large and unstructured data a data management system was designed, namely data cleaning, understanding data generating analytical categories and concepts with the help of N-Vivo program version 11.

In addition, the researchers also obtained the assistance of research participant to review and confirmed the gathered interview that has been transcribed. Earlier researchers have also obtained expert judgment to assess the content validity of the interview protocol as done by previous researchers such as Celinea (2018) and Nadziroh (2018) where the interview protocol was distributed to four assessors for content verification purposes. The reliability of this study has also gone through an expert verification process (inter-rater reliability) by taking into account the value of expert consent through the calculation of the average value of the evaluation of the four appointed experts.

\section{Research Findings}

The results of the study found four themes that have emerged in this study, namely; (i) religious practice (ii) client willingness and (iii) Ad-Din psychological approach and (iv) Islamic Creative Art Therapy (I-CAT).

\section{Religious Practice}

This religious approach is more towards religious practices such as prayer, $d u^{\prime} a, z i k r$, fasting and awareness as well as cultivating religious values such as patience, forgiveness and gratitude for every gift from Allah. According to Counselor 2, this religious element is included in a counseling session when the client himself or herself touches on religious values. When the client has stated their religious values, it means the client's willingness to have a discussion through the lens of religion. If the client is ready, the counselor does not hesitate 
to instill religious values into the counseling session by suggesting behaviors such as increasing fasting and zikr in order to fight lust as well as avoid all forms of immorality;

I [the counselor] look at the openness of the client, like my client, he is open to religion. It is not me imposing religion upon him. As for me I like to use the questioning method in my session... at the beginning of the session I did not asked, but at the end of the session I asked the client, "Are you mentioned something, same-sex relationships...?" The client replied, "Aah... indeed I like [the same-sex]." I [the counselor] kept asking, "When you pray what happens to your emotions?" Then the client replied, "Sometimes I feel like a hypocrite because my passions can't be controlled." The clients themselves who will mention their value, most of them know the value themselves; know that this thing [homosexual behavior] is wrong due to its pleasure, sensation and addiction. Therefore, when this thing [homosexual behavior] is there, I asked the client to fast and do a lot of zikr to avoid doing things that are towards homosexuality. (Counselor 2)

Counselor 3 who uses a religious approach with willingness from the client himself supports the above statement. Here, the counselor played a role to touch from the perspective of client's religious practice in terms of prayer, relationship with God, way of life and so on. The counselor has asked the client to do the prayer of repentance and recite as well as trying to understand each verse of the Qur'an. The purpose of doing this is to see if the client is calmer from all the problems, he faces. The client is said to be willing to perform the assigned task;

After the client fully accepted the counselor, the client himself stated that what he was doing was wrong and awareness arose so at that time I played the role of a Muslim. I can go into religious perspective subtly, such as "Pulling a strand of hair from the flour" [Malay proverb meaning to do something subtly without creating chaos]. I ask if the client is willing to change. When the client said yes, I asked him to perform the prayer of repentance, recite, and understand every verse of the Quran so that he is calmer. (Counselor 3)

\section{Client Willingness}

Counselor 1 explained that he used this religious approach in the middle of the session; it was also with the client's willingness to openly accept religious values in the session. This religious element also arises in the session after the client gains the awareness and insight to change as well as having the realization of what the client is doing is wrong. Once the client has gained awareness, the counselor will use questioning skills and emotional reflection to ensure that everything said reflect client's true intentions. Counselor 1 also said he did not like to include religious values in the session, because he worries the client would be uncomfortable. However, when the client himself said of his willingness to incorporate religion into the session, then as a Muslim it is Counselor 1 responsibility to help the client change for the betterment especially concerning his relationship with god;

I [the counselor] again used many elements of Islamic perspective in the fourth session and the fifth session. I started mentioning the Islamic perspective after he himself mentioned it and realized exactly what was happening because his relationship with Allah was far away. When he himself began to mention [of religion] I myself asked, 
"What kind of relationship?" He says he sometimes does his prayers and sometimes he he doesn't. Two weeks after terminating the session, he felt that the last [prayer] was what he was looking for, the emptiness in his life was prayer. (Counselor 1 )

Counselor 4 who explained this religious approach was used after the client began to realize the act done was wrong and had begun to mention himself having long strayed far from God in terms of his prayers and du'a supported Counselor 1's statement. This awareness is like the client is willing to accept the Islamic approach in a session without coercion by the counselor. After that awareness arises, counselors use counseling skills in tandem with the Islamic approach in an effort to help the client achieve the goal of returning closer to Allah;

When the client achieved insight then what is our next action? Then I include the Islamic approach strategy in the session when the client starts to realize what he is doing wrong and when the client himself mentioned he is getting further and further away from god. So I will ask, "How far away is he from God?", "What did he mean just now?" When he himself has started [willingness], he is getting closer to Allah. Therefore, in the end I am a little more towards the Islamic perspective. In fact, I rarely use the Islamic perspective in the session, but when the client himself has started to mention of his willingness, I see that as an obligation, because the client also has the same religion as me. (Counselor 4 )

Counselor 8 who emphasized that the Islamic approach can be used in a session once the counselor has gained full trust from the client also agreed on the above statement. If this matter is touched on from the beginning, it is likely to cause discomfort to the client in the session as if the counselor is preaching instead of doing counseling. Therefore, establishing a good relationship with the client is of utmost importance. After gaining trust, the client will narrate his main problem and at the same time, there will be an awareness to change back to origin. When the client himself consciously wants to change back to origin, the counselor proceed to touch on religious practices that can improve the client's personality and spirituality;

Like me [the counselor] myself, once the client trusts me, the rapport is there. The client himself states that what he is doing is wrong and awareness arises. So then, we play a role as a Muslim... can proceed from religious perspective subtly. Nontheless, if the counselor has punished the client at the beginning of the session thus the counseling session will not go on smoothly because the issue of gays and lesbians is very sensitive... if early in the beginning we have involved religious issues with them. (Counselor 8)

\section{Ad-Din Psychological Approach}

In addition to the emphasis on religious practices in the session, the counselors also discussed the use of Ad-Din psychological approach when conducting sessions with gay and lesbian clients. The counselors use this alternative when the client has the awareness to change towards a better life. Sometimes, the client's awareness of this change occurs in the middle of the session when the client begins to feel the emptiness of the soul. This change is not something that is easy for gays and lesbians because it takes time. Therefore, to stimulate the change counselors use a variety of theories in the session including integrating religious 
elements into their souls. This religious approach is used with the consent of the client. Thus, the application of this Ad-din psychological approach is implemented when the client is ready and expresses his desire to change for the better. According to Counselor 7, these changes should be on the client's own volition, without coercion from anyone. This is because, according to Counselor 7 , if a change occurs due to coercion and persuasion from another party, it is likely that the change will only last for a short period;

I use this Ad-Din psychological approach when the client already sees he wants to change. I will ask the client, "What does Islam want in human life?" Let the client explain. Not us who give the sermon to him, because the client who wants to change... not us. But, I'm afraid their change is only temporarily, a year or two after that back to the the old lifestyle. (Counselor 7)

Counselor 7's statement is supported by document analysis and a description of the ways AdDin psychological approach is conducted on the client. It encompasses the exploration and understanding of lust by the client. This stage is important to instill confidence and support of the client that the counselor cares about the client. Counselors have also carefully observed and identified client's problem from mental, emotional and behavioral aspects. Exploration and understanding based on taqwa, counselors explore the client's problem based on discussion, guidance and the provision of information based on taqwa.

The above statement is also supported by Counselor 5 who mentioned that the use of Ad-Din psychological approach is only used in the middle and end of counseling sessions, depending on the seriousness of the issue being handled. This religious approach should not be used during the beginning of a counseling session, if this happens, the client will assume the counselor cannot accept their situation and identity. Once the client has begun to gain trust in the counselor, only then the counselor decides in using religious alternatives in the session such as the use of Ad-Din psychological approach;

I [counselor] also used Ad-Din psychological approach in the session, again one has to remember this Islamic approach, we do not use during the first session, this Islamic approach must be incorporated in the middle or end of the session... and it is also up to the issue brought up by the client. (Counselor 5)

\section{Islamic Creative Art Therapy (I-CAT)}

In addition to Ad-Din psychological approach, counselors also use the Islamic Art Therapy (ICAT) approach to handle gay and lesbian cases. This approach is one of the innovations made in helping relationships that is increasingly used to assist clients. The purpose is to make I-CAT as a $d a^{\prime}$ wah approach for helpers and counselors as well as to strengthen the client's spiritual practice. For Counselor 5, the skills in the use of I-CAT is an added value to him. He added that he implemented this approach when the client is ready to change, usually in the middle of a counseling session. The application of this approach is also implemented after obtaining consent from the client himself;

I also use Islamic Art Therapy (I-CAT) extensively in counseling sessions with gay and lesbian clients. Therefore, this is also a benefit for me in helping clients. In the process of helping, clients together with their counselors will go through a lot of experience 
together. There are clients who at the beginning of the session informed that he does not want to change because he really likes his lifestyle now but in the middle of the sessions has the willingness to change. (Counselor 5 )

\section{Discussions}

Based on the findings of the study, counselors explained that in addition to the use of conventional theories from the west, counselors have used a religious approach when conducting counseling sessions with gay and lesbian clients. The religious approach presented involves encouraging clients' change and it is conveyed through the implimentation of religious practices in the counseling process such as prayer, $d u^{\prime} a$ and zikr as well as strengthening religious values such as forgiveness and awareness to repent. Therefore, the counselor has inserted religious advice to the client in the session. The client is also advised to deepen their religiosity by praying, maintaining a good relationship with Allah. While at the same time encouraging and cultivating good qualities such as being patient, forgiving and helpful to one another. This religious approach is used to encourage clients to change for the betterment. This is in line with previous studies showing a positive effect on clients when spiritual elements are applied in counseling sessions (Capuzzi \& Gross, 2012; Cashwell \& Young, 2011; Dini Farhana, 2016). These religious elements are used when the client is ready, open and comfortable with the counselor. Dini Farhana (2016) explains the religious elements included in counseling are extensively illustrated through counseling adaptation studies in contexts other than the West such as in Korea, Japan Thailand and Egypt. Kelly et al. (2009) and James (2002) state that religious approach is relevant, ethically appropriate and significant in secular life. They agreed that ethics and religion have basis and legitimacy in dealing with life issues.

The results of the study also found that some counselors are quite cautious in the use of religious approaches in sessions and will first give space to clients to bring up this religious element in the discussion. In addition, counselors will also make referrals to parties who are more knowledgeable about religious matters if they feel unable to handle the case. The ability of counselors to adopt this religious approach also depends on the training and multicultural competence of the counselor handling a case. As contained in subsection F.11.c of the Code of Ethics for Counselors by the Malaysian Board of Counselors which mentions the diversity of counselors' competencies depends on the ability of counselor educators to actively incorporate these competencies into the training and supervisory practices they undertake (Board of Counselors Malaysia, 2011). This religious approach is seen as a potential counseling approach in the context of Malaysia's multicultural society (Wong \& Awang 2012). As Islam is the official religion of Malaysia it is appropriate to provide specific training to Muslim trainee counselors on the need to have the confidence and the ability to assimilate the Islamic approach into ongoing sessions especially if clients' has been shown their willingness. Dini Farhana (2016) and Asmah Bee (2004) also emphasize the point where more attention should be given to the training and competence of cultural diversity in the aspect of religion to ensure effective counseling services. Meanwhile, counselor should also understand of the possible conceptual differences that includes religious and life experiences between Muslim gays and lesbians living in the west as compared to those residing in Malaysia (Mohammed Yusof \& Nasrudin, 2018).

There are several previous studies that have emphasized religious counseling approaches in helping gay and lesbian clients to change, for example the studies by Amran \& Noriah (2014) 
and Rafidah (2014), have discussed aspects of religious and counseling procedures used to address the spread of gay and lesbian influences in society. It can be seen that gay and lesbian influences nowadays require effective alternative treatments to help them return to origin. What is most important is that the change is gradual rather than drastic so that the change experienced can be lasting. Based on past studies returning to religious teachings is one good approach (Subhi et al., 2011). The methods of appreciating their respective religions are according to certain procedures that can help correct these gays and lesbians from the current values they hold. For example, prayer, repentance, $d u^{\prime} a$, getting closer to God and appreciating the practice of religious teachings can help repair the heart and faith (Amran \& Noriah, 2014).

Finally, the study also found that counselors tend to combine religious approaches along with other conventional theories in an integrative manner including in conducting counseling sessions with gay and lesbian clients. The findings of this study are consistent with previous studies by Mazidah Dagang et al. (2014) and Meyer (2010) who explained that counselors integrate religious approaches with conventional theories as well as existing interventions as one of the aspects taken into account in the counseling process conducted. Although this study found that counselors use religious models such as Ad-Din psychological approach, yet its use is not comprehensive and in-depth. This may be because the counselor only has a basic level of knowledge that limits its use. Through observation found that counselors are more likely to include religious elements such as prayer, $d u^{\prime} a$, zikr, fasting and recitation of the Qur'an as techniques towards fostering positive change in the gay and lesbian clients they handle.

\section{Conclusion and Implications}

Overall, the findings of the study have clarified that experienced counselors who has a strong religious foundation implement religious approach in helping to address issues faced by gay and lesbian clients. The counselor also explained that religious approach is used depending on the needs of the case, among other things when the client expresses a desire to change and intention return to origin. Since the struggle between religion and sexuality is a great, opening the mind and reminding the client about the concept of God's grace is very important. At the same time educating clients to use religious techniques in finding the desired peace. Finally, counselor educators need to be better prepared to adopt a religious approach in their training and supervision provided to trainee counselors at the university.

This study gives implications to counselors the need to improve self-competence on the religious approach as an important skill in addressing various societal issues including gays and lesbians especially when they want to return to origin. In addition, counselor educators at universities need to be more competent and prepared in touching on religious approaches while providing training and supervision to trainee counselors. At a higher level, the drafters of counseling programs at universities as well as the Board of Counselors Malaysia themselves need to formulate a specific subject on religiosity and spirituality in an effort to improve the competence of counselors dealing these issues. Furthermore, religion and spirituality are still the main tenets of Malaysian society. If all these implications are given due attention then the level of competence and professionalism of counselors can be increased in an effort to help the needy, including gay and lesbian clients. For gays and lesbians, they will be more willing to see a counselor without hesitation on issues of bias, prejudice and discrimination. 


\section{References}

Amran, H., \& Noriah, M. (2014). Alternatif keagamaan dan kaunseling: Sebagai rawatan utama mengatasi permasalahan homoseksualiti. Journal of Human Development and Communication, 3, 79-92.

Bee, A. Md. N. (2004). Dimensi agama dan spritual dalam amalan kaunseling. Proceedings International Seminar on Islamic Thoughts. Bangi: Universiti Kebangsaan Malaysia.

Board of Counselors Malaysia. (2011). Counsellors Code of Ethics. Kuala Lumpur: Board of Counselors Malaysia.

Capuzzi, D., \& Gross, D. R. (2012). Introduction to the counseling profession. (6th ed.). New York: Routledge.

Cashwell, C. S., \& Young, J. S. (2011). Integrating spiritually and religion into counseling. An introduction. In. C. Cashwell \& Young (Eds.) (2nd ed.). Integrating spirituality and religion into counseling: A guide to competent practice, (pp. 1-24). Alexandria, VA: American Counseling Assocition.

Celinea, L. (2018). Amalan Pembelajaran kemahiran membaca bahasa Melayu dalam kalangan murid Bidayuh. Tesis Dr. Fal. Fakulti Pendidikan, Universiti Kebangsaan Malaysia.

Corey, G. (2009). Theory and practise of counseling and psychotherapy. (8th ed.). Pacific Grove: Thomson Brooks/Cole.

Creswell, J. W. (2012). Qualitative inquiry and research design: Choosing among five approaches. (3rd ed.). Thousand Oaks, California: Sage Publications, Inc

Dini, F. (2016). Tesis of counseling strategies based on multicultural community welfare in Malaysia. Tesis Dr. Fal. Fakulti Pendidikan, Universiti Kebangsaan Malaysia.

Hill, C. E., Thompson, B. J., \& William, E. N. (1997). A guide to conducting consensus qualitative research. The Counseling Psychlogist, 25, 517-572.

Ivey, A., Ivey, M., Myers, J., \& Sweeney, T. (2005). Developmental counseling and therapy: Promoting wellness over the lifespan. Boston: Lahaska Press.

James, S., \& Prilleltensky, I. (2002). Culturaldiversity and mental health: Towards integrative practice. Clinical Psychology Review, 22(4), 1133-1154.

Kelly, U. A. (2009). Migration and education in a multicultural world. New York: Palgrave Macmilan.

Mazidah, M. D., Raja-Zirwatul, A. R. I., \& Azlina, A. B. (2014). Counselors spritual competence in Malaysia. Asian Social Science, 10(10), 182-187.

Meyer, I. (2010). Identity, stress, and resilience in lesbian, gay men, and bisexuals of color. Counseling Psychologist, 38(3), 442-454.

Miles, M. B., \& Huberman, A. M. (1994). Qualitative data analysis: An expanded sourcebook. (2nd ed.). Thousand Oaks, California: SAGE Publications Inc.

Yusof, M. D. G., \& Nasrudin, N. (2018). Religious and sexual identity conflict among same-sex attracted Muslim men: A conceptual differences of life experience between Western and Muslim majority countries. Jurnal Psikologi Malaysia, 32(4), 133-149.

Nadziroh, M. Z., Ku Suhaila, K. J., Zuria, M., Hamizah, N. A. R., \& Sabihah, J. (2018). Cabaran aplikasi modul terapi filial dalam kalangan ibu bagi menangani isu tingkah laku kanakkanak. Jurnal Pendidikan Malaysia, 43(3), 21-30.

Nike, W., Amirah, D., \& Asti, M. (2020). Kompetensi multicultural kaunseling lesbian gay biseksual dan transgender dalam perspektif Islam. Psikobuletin: Buletin IImiah Psikologi, 1(2), 129-138. 
Noor, H. H., Kamal, A. A. R., \& Rosni, W. (2016). Metodologi dakwah terhadap golongan lesbian, gay, biseksual dan transgender (LGBT). Jurnal Pengajian Islam, 9(11), 211-224.

Norliah, K., \& Mahadi, A. H. (2006). Masalah sosial: Isu dan cabaran institusi keluarga. Prosiding Kolej Universiti Teknologi Kebangsaan Malaysia. Batu Pahat: Kolej Universiti Teknologi Kebangsaan Malaysia.

Patton, M. Q. (2002). Qualitative research and evaluation methods. (3rd ed.). Thousand Oaks, CA: Sage Publications Inc.

Pedersen, P. (1989). Developing multicultural ethical guidelines for psychology. International Journal of Psychology, 2(4), 144-159.

Rafidah, A. M. J. (2014). Pengenalan profesion kaunseling di Malaysia. In R. A. M. Jaladin \& P. L. Lau (Eds.), Isu profesionalisme kaunseling di Malaysia (pp. 1). Kuala Lumpur.

Roslee, A., Mohamed S. M., \& Sulaiman, S. M. N. (2008). Pendekatan Kaunseling Daripada Perspektif Islam. Prosiding International Conference on the Education of Learner Diversity. Bangi: Universiti Kebangsaan Malaysia.

Marican, S. (2005). Kaedah penyelidikan sains sosial. Kuala Lumpur: Pearson Malaysia Sdn. Bhd.

Siti Hajar, J. (2020). Meneroka kompetensi kaunselor dalam pengendalian klien gay dan lesbian. Tesis Dr. Fal. Fakulti Pendidikan, Universiti Kebangsaan Malaysia.

Siti Hajar, J., Nasrudin, S., \& Salleh, A. (2020). Kompetensi kesungguhan dan nilai kaunselor dalam mengendali kaunseling gay dan lesbian. Jurnal Psikologi Malaysia, 34(3), 53-64.

Subhi, N., Geelan, D., McMahon, M., Jusoff, K., Mohamad, S. M., Sarnon, N., ... Alavi, K. (2011). A better understanding of the potential conflict between Christianity and homosexuality. World Applied Sciences Journal, 12(S), 13-19.

Sperry, L. (2007). The ethical and professional practice of counseling and psychotherapy. Boston: Allyn \& Bacon (Pearson).

Sperry, L. \& Shafranske, E. P (Eds). (2005). Sprituality oriented psychotherapy. Washington, DC: American Psychological Associatiton.

Wong, L. P., \& Awang, J. (2012). Midlife crisis perceptions, experience, help-seeking and needs among multi-ethnic Malaysian woman. Women \& Health, 52(8), 804-819.

Yin, R. K. (2015). Qualitative research from start to finish. (2nd ed.). New York: The Guilford Press 